\title{
THE EFFECTIVENESS OF DigITAL STORYTELLING ON LANGUAGE LISTENING COMPREHENSION OF KINDERGARTEN PUPILS
}

\author{
Amor F. Loniza ${ }^{1}$, Aslina Saad ${ }^{2}$ and Mazlina Che Mustafa ${ }^{2}$ \\ ${ }^{1}$ Philippine Normal University South Luzon, Lopez, Quezon Philippines \\ ${ }^{2}$ Universiti Pendidikan Sultan Idris 35900 TanjongMalim, Perak
}

\begin{abstract}
This study investigated the effectiveness of Digital Storytelling on the language listening comprehension of the pupils. The researchers used quantitative research design with mixed data collection. To evaluate the effectiveness of the KiDS material, a Quasi-experimental with pre and posttest was utilized. Findings revealed that the experimental group attained a very high score on their language listening comprehension test after the implementation of the material that shows a significant difference between the control and experimental group. To conclude, digital storytelling is one of the essential tools in teaching language listening comprehension. With suitable elements and appropriate storyboard it can help motivate the pupils and improve listening skill. Therefore, the use of KiDS material is recommended to make the teaching of language more effective.
\end{abstract}

\section{KEYWORDS}

Kindergarten Digital Storytelling, Story Telling, Kindergarten Learners, Language Listening Comprehension, Technical Standards.

\section{INTRODUCTION}

For many years, technology is a massive reformation in education. It is a great movement for better and improvement of instruction especially for the young minds. It is also the main reason on the changes in the curriculum to integrate technology as a tool for instruction. Furthermore, the need for these technologies was brought out by various studies and literature highlighting its significance in increasing learning experiences and student learning outcomes. This significance is not only exclusive to a particular learning group but also transcends early childhood education learners [23].

In school, multimedia, an innovative tool, has become one of the highlights of today's teaching. Being widely used in the teaching-learning process multimedia has conquered the heart and soul of the learners thus, learners' interest and attentiveness have increased and deepened, making them more attentive and participative. There were numerous beliefs that the changing scene requires the thought of the structure and culture of the schools and the classrooms, alongside what educators instruct and how they show it. Likewise, educators find multimedia more relevant as they go along using it. Researchers have also revealed the impacts of using technology in teaching.

Even though digital storytelling has been practiced for more than two decades, a limited amount of research has been conducted on this technology especially as it has been used in educational 
The International Journal of Multimedia \& Its Applications (IJMA) Vol.10, No.6, December 2018

setting [20]. Therefore, further study needs to be done to examine the feasibility of using digital storytelling in kindergarten learners to evaluate its efficacy on their language listening comprehension achievement. Hence, listening skills is absolutely necessary in one's academic success since it has been regarded as the most widely used language skill in the classroom [16]. On the other hand, there were numerous findings from previous researches regarding the significance of listening skills to the pupils. In fact [5] mentioned in their research that listening plays an important role in individuals' day-to-day undertakings as well as learning activities. Thus, the proficiency of the pupils are obtained and developed naturally at the very early years of their lives. Hence, the children can understand, synthesize, evaluate more efficiently what they listened to if they are taught effectively on their own spoken language. In addition, listening is the first language skill that children develop and it is the most dominant communication in the classroom and everyday life. One by which the skills of listening can be developed is through storytelling [17]. Consequently, language learning should be supported with lots of visuals or real objects in the classroom.

Moreover, instructional materials must be properly selected and organized to give opportunities for children develop their language and proficiency in a playful and enjoyable context [24]. Such idea correlates with the Department of Education's goals which is to emphasize the importance of the learners' receptive and productive skills in such a way that viewing must support listening and reading. This study evaluated the effect of Kindergarten Digital Storytelling (KiDS) material on the language listening comprehension of the pupils in the Philippines.

The researcher found out the need to conduct further research on the use of digital storytelling material to assess its efficacy on children's language learning [18]. Furthermore, there is an insufficient research on how digital storytelling contributes to improve children's listening comprehension [12]. Additionally, [5] emphasized that most of the studies on the use of digital stories in language teaching focus on foreign language education. There are few studies in which digital stories are used for mother language teaching. Therefore, researchers could conduct further studies on the use of digital stories to develop various language skills in mother language education. Likewise, the unavailability of the ready-made digital storytelling as instructional materials in the country for mother tongue that can be used by the teachers in kindergarten is another problem. As a result, most of the teachers are not yet familiar of it so they do not use digital storytelling in teaching and learning process.

Based on the above findings, the need to conduct the study on the effectiveness of kindergarten digital storytelling on the language listening comprehension of the pupils is still necessary.

This study evaluated the effect of the KiDS material on the language listening comprehension of the pupils. Thus, this study seeks to answer the following questions:

- Is there a significant difference between the pretest and posttest mean scores of the control group?

- Is there a significant difference between the pretest and posttest mean scores of the experimental group?

- Is there a significant difference between the control and experimental group in terms of language listening comprehension after the implementation of the material?

From the above objective and questions the following hypothesis can be derived: 
The International Journal of Multimedia \& Its Applications (IJMA) Vol.10, No.6, December 2018

- $H_{O}$ : There is no significant difference between the pretest and post-test of the control group

- $H_{O}$ : There is no significant difference between the pretest and post of the experimental group.

- $H_{O}$ : There is no significant difference between the control group and experimental group on their language listening comprehension of the kindergarten pupils

\section{LITERATURE REVIEW}

In a study of [25] about the effect of using video materials in the teaching it was revealed on his study that listening skills of the students increased significantly in their listening comprehension ability after learning with videos and students had positive attitudes towards using videos in teaching listening skill [2]. With this study, it clearly supports the present study on digital storytelling and its effectiveness on their language learning. It positively shows the effectiveness of the video material used for language learning.

On the other hand, the study of [14] shows another version of study in digital storytelling. The results of the study showed that storytelling was an effective pedagogical instrument in improving the language skills of learners who demonstrated interest and pleasure in participating in storytelling activities, whereas little progress was observed in learners who has no in storytelling. In the study above, it can be concluded that despite students were using the digital storytelling in class, students should be properly oriented and well organized in class. If the students are not properly oriented, they may only have low progress even the teachers use digital storytelling. Teachers should be aware that their duty in facilitating the digital storytelling is important.

Likewise, [2] carried out a seven-week study to investigate the role of storytelling in enhancing the language skills of a group of forty male and female ESL adult learners, between thirty and fifty years of age, who had used English as a foreign language (EFL) for six to twelve years. He pointed out that, learners should also be assessed through other methods, such as continuous classroom activities, and have the results of their three-hour test compared to their performance in the classroom activities.

It can be concluded that, to meet the goal in helping the students for the development of the language skills, the study shows that there should have a continuous assessment and there should have some continuous classroom activities so that mastery on the skills would be mastered.

The studies by [15] and [2] offer empirical evidence on the importance of storytelling in promoting the development of receptive and productive language skills, by providing learners with the opportunity to actively work on such language skills in a fun and engaging manner.

\section{Methodology}

\subsection{Research Design}

To determine the effects of KiDS material the present research utilized Quantitative Research Design with mixed data gathering procedure. According to [5], in quantitative research specifically, the researcher identifies problems based on trend in the field or on need to explain why something occurs. This study used quantitative design since it investigates on the effects of the developed Kindergarten Digital Storytelling material on the language listening comprehension 
The International Journal of Multimedia \& Its Applications (IJMA) Vol.10, No.6, December 2018

skill of the pupils. Lesson plans with formative tests, achievement test for the pupils and the rating scale were developed to realize the said objective.

This research likewise used a quasi-experimental design with treatment and control group, employing pretest and posttest. Both group administered a pretest to determine the level of comprehension before the implementation of the program. On the other hand, only the experimental group received an instruction using KiDS, while the control group used traditional way of teaching with the use of big books and pictures in teaching language.

To evaluate the effect of Kindergarten Digital Storytelling material on language listening comprehension skills of the pupils, the post test on the language learning achievement test was administered. It is done through the help of the teacher. The teacher reads each question and waits for the pupils to answer. Likewise, the formative test after every lesson was administered through the help of the teachers. The result was checked and the data was analyzed using t-test and SPSS.

Consequently, this research employed purposive sampling which is also a type of a nonprobability sampling method [7]. Participants in the study were composed of twenty-seven kindergarten pupils for both control and experimental group. They were purposely selected in DepEd Lopez West District of Lopez Quezon, whose classrooms are fully equipped with ICT materials that can be used during the implementation of the KiDS material. Likewise, a partner school of Philippine Normal University with Memorandum of Agreement to where our student teachers are holding their internship activity.

The selected participants were equally divided into two groups for experimental and control group. The teacher who used the developed material was trained and provided enough knowledge on how to use and manipulate the material. Only one group which is the experimental group used the KiDS material, on the other hand, the control group did not use the said instructional material but rather used the traditional materials in teaching language. Hence, both groups were provided by a lesson matrix/lesson plan that served as the guide of the teacher in facilitating the teaching and learning process in language.

\subsection{Data Gathering Instrument}

To evaluate the effectiveness of the developed material the researcher constructed a language listening comprehension test, which is composed of a 15 -item test for pretest and posttest. Table of specification (TOS) was made for achievement test to establish its validity. The 15 item-test was based on the five comprehensive lessons in language, which are included in the KiDS material. Lessons, objectives and activities were adapted in The Philippine Kindergarten Curriculum of the DepEd, which are digitized. On the other hand each lesson has a formative test, which is congruent to the learning objective of the lesson. The objectives of the lessons are based on language listening comprehension of the pupils stated in the Teachers' learning manual. This is to evaluate the language learning comprehension of the pupils for every lesson.

The researcher constructed three items for each lesson. A multiple type of test was constructed and each is compose of three choices with only one correct answer for each question. The said instrument went through a content validation by the kindergarten teachers and coordinator. Their suggestions and comments were taken into consideration in revising the instrument.

The researcher seeks permission to the principal of the school to pilot test the instrument. When the principal approved the request, pilot testing was conducted in a class and was administered into two intervals with forty (40) kindergarten pupils. The answer to the test was categorical in nature thus, the result from these two-pilot testing was analyzed using correlation. 
The International Journal of Multimedia \& Its Applications (IJMA) Vol.10, No.6, December 2018

For establishing the reliability of instrument, the odd-even strategy was utilized. The examination papers (instruments) were numbered, and the mean percentage scores of even-numbered instruments were correlated with the scores of odd-numbered instruments.

The correlation analysis resulted to a coefficient of correlation (Pearson r) 0.8589 , which is interpreted as a "strong positive correlation". The result confirmed that the instrument (or the exam questionnaires) has internal consistency. This manifests that the instrument is suited and applicable to the kindergarten pupils. Therefore, the instrument was used for the pre and post-test of the experimental and control group.

Observation was also done during the implementation to gain information about the teaching and learning process as well as to describe how the pupils listen and participate during the discussion with the use of the developed material.

The result of the evaluation phase was served as the primary data of this research study. To determine the validity and acceptability the researcher performed the data processing. The rating was tabulated and organized into tables. The result was analyzed and subjected to weighted mean. A data-gathering instrument is reliable if it is able to elicit stable consistent and dependable data from the respondents. The arithmetic means or simply the mean refers to the sum of all the given values or items in a distribution divided by the number of values or items summed.

Moreover, to determine the effect of the KiDS material on the language listening comprehension of experimental and control group, the researcher employed t-Test for Independent group samples. The independent group t-test is a parametric statistical test that compares the means of two different samples of participants. It indicates whether the two samples perform so similarly that we could conclude they are likely from the same population, or whether they perform so differently that we conclude they represent two different populations [14].

\section{FINDINGS}

To evaluate the effect of the material on the language learning of the kindergarten pupils focusing on their language skills the implementation was conducted to the control group who used the traditional way of teaching language and the experimental group who utilized the KiDS material.

\subsection{Significant difference between the pretest and posttest mean scores of the control group.}

This part contains the significant difference between the pretest and posttest mean scores of the control group. Data shows the result of the pretest and posttest after the conduct of the research.

Table 4.1 Significant difference between the pretest and posttest of the control group

\begin{tabular}{|l|l|l|l|l|l|}
\hline $\begin{array}{l}\text { Control } \\
\text { Group }\end{array}$ & Mean Scores & Std. Dev. & p-value & Decision & $\begin{array}{l}\text { Interpretatio } \\
\mathbf{n}\end{array}$ \\
\hline Pre-Test & 10.2 & 3.7780 & 0.247 & Accept Ho & $\begin{array}{l}\text { Not } \\
\text { Significant }\end{array}$ \\
\cline { 1 - 3 } & & & & & \\
\hline
\end{tabular}


The International Journal of Multimedia \& Its Applications (IJMA) Vol.10, No.6, December 2018

Table 4.1 shows the significant difference between the pretest and posttest mean scores of the control group which contains 27 kindergarten pupils. To determine if there is a significant difference on the performance of the subjects under the Control Group before and after the introduction of the learning module, a t-test was performed.

As can be inferred from the table, the mean scores of the subjects is 10.2 and 11.2 in their pre-test and post-test respectively, resulting in a -1.0 mean difference. Further inference from the table revealed a p-value of 0.247 , which is greater than the level of significance $(\alpha=0 / 05)$. Hence, the null hypothesis is accepted which establishes that there is no significant difference between the pretest and posttest mean scores of the subjects under the control group.

Table 4.2 Significant difference between the pretest and posttest scores of the experimental group.

\begin{tabular}{|l|l|l|l|l|l|}
\hline $\begin{array}{l}\text { Experimental } \\
\text { Group }\end{array}$ & Mean Scores & Std. Dev. & p-value & Decision & $\begin{array}{l}\text { Interpretatio } \\
\mathbf{n}\end{array}$ \\
\cline { 1 - 2 } Pre-Test & 9.6 & 1.8930 & 0.000 & Reject Ho & Significant \\
\cline { 1 - 3 } & 14.04 & 1.2741 & & & \\
\hline
\end{tabular}

Table 4.2 reveals the significant difference between the pretest and posttest mean scores of the experimental group. The research used two groups of respondents the first group was control and the other group was the experimental group. Both groups contain of 27 kindergarten pupils who undergone to experiment of the material. To determine if there is a significant difference the researcher used the pretest and the posttest both of the group took the test. The main goal of the research is to develop the language learning of the kindergarten pupils specifically their listening skills. The experimental group used the material as intervening materials after the experiment on the performance of the subjects under the Experimental Group before and after the introduction of the learning module, a t-test was performed.

After the data gathered, as can be inferred from the table, the mean scores of the subjects is 9.6 and 14.04 in their pre-test and post-test respectively, resulting in a -4.44 mean difference. Further inference from the table revealed a p-value of 0.000 , which is less than the level of significance $(\alpha$ $=0 / 05)$. Hence, the null hypothesis is rejected which establishes that there is a significant difference between the pretest and posttest mean scores of the subjects under the experimental group.

\subsubsection{Significant difference between the control group and experimental group after the experiment in terms of language learning}

This part exemplifies the result of the data on the significant difference between the control group and the experimental group. Data was collected through KiDS material which was measured by the pretest and the posttest given to the respondents. Table below was the summarized representation of the data. 
The International Journal of Multimedia \& Its Applications (IJMA) Vol.10, No.6, December 2018

Table 4.3 Significant difference between the control and experimental group after the experiment

\begin{tabular}{|l|l|l|l|l|l|}
\hline Group & $\begin{array}{l}\text { Mean } \\
\text { Posttest } \\
\text { Scores }\end{array}$ & Std. Dev. & p-value & Decision & Interpretation \\
\hline Control & 11.2 & 2.2148 & 0.000 & Reject Ho & Significant \\
& & & & & \\
\hline Experimental & 14.04 & 1.2741 & & & \\
\hline
\end{tabular}

To determine if there is a significant difference between the control group and experimental group after the experiment in terms of language learning specifically on their listening skills, a ttest was performed.

As can be inferred from the table, the posttest mean scores of the subjects are 11.2 and 14.04 for control and experimental group respectively, resulting in a -2.84 mean difference. Further inference from the table revealed a p-value of 0.000 , which is less than the level of significance $(\alpha$ $=0 / 05)$. Hence, the null hypothesis is rejected which establishes that there is a significant difference between the control group and experimental group.

\subsection{The Effect the KiDS Material on the language listening comprehension of the pupils.}

The main purpose of the research was to identify the effectiveness of the KiDS material to language learning specifically on their listening skills. Two types of data were presented in this part, the first one shows the significant difference on the impact of the KiDS materials to the experimental group over the control group. While the second part depicts the observations of the teachers on the effect of the experimentation to the two groups of learners - the control and the experimental groups.

Table 4.4 Effectiveness of the KiDS Material

\begin{tabular}{|l|l|l|l|l|l|}
\hline \multicolumn{1}{|c|}{ Group } & \multicolumn{1}{|c|}{ MPS } & Std. Dev. & p-value & Decision & $\begin{array}{c}\text { Interpretatio } \\
\mathbf{n}\end{array}$ \\
\hline Control & 63.23 & 22.8249 & $0.000 * * *$ & Reject Ho & Significant \\
\hline Experimental & 85.69 & 15.7652 & & & \\
\hline
\end{tabular}

Table 4.4 shows the effect of the KiDS material. To assess the interim effect of the material implemented in the experimental group, the mean percentage score (MPS) of the results of the evaluation for control and experimental are compared. The MPS in the control group is 63.23, while the MPS for experimental is 85.69. The following table details the result of the t-test. The table above verifies that there is indeed a positive effect on the learning process of students upon the use of the KiDS material since the experimental mean percentage score (85.69) is higher than the mean percentage score of the control group (63.23).

The table revealed that the decision is reject the hypothesis, which found out significant. Generally, the KiDS material has a great impact on the language listening comprehension as proven by the result of the evaluation made to the control and experimental group during the implementation of the KiDS material.

During the observation the impact of the material on the setting, mood, attentiveness, motivating the pupils and the result of the test were given emphasized. The observation were summarized in Table 4.5. 
The International Journal of Multimedia \& Its Applications (IJMA) Vol.10, No.6, December 2018

Table 4.5 Result of the Observation

\begin{tabular}{|ll|ll|}
\hline \multicolumn{2}{|c|}{ Control Group } & \multicolumn{1}{|c|}{ Experimental Group } \\
\hline 1. & Listen throughout the storytelling & $\begin{array}{l}\text { Listen and enjoying the storytelling while } \\
\text { watching. }\end{array}$ \\
\hline 2. & Kindergarten pupils are passive listeners. & $\begin{array}{l}\text { 2. } \\
\text { Kindergarten pupils are motivated to listen, } \\
\text { able to answer questions after the } \\
\text { storytelling. }\end{array}$ \\
\hline $\begin{array}{l}\text { 3. } \\
\text { Kindergarten pupils able to answer the post }\end{array}$ & $\begin{array}{l}\text { 3. } \\
\text { texperimental group of kindergarten pupils } \\
\text { have got high score on their post }\end{array}$ \\
\hline $\begin{array}{l}\text { Kindergarten pupils able to enhance their } \\
\text { language through listening comprehension. }\end{array}$ & $\begin{array}{l}\text { 4. } \\
\text { Kindergarten pupils in the experimental } \\
\text { group develop higher listening } \\
\text { comprehension on their language. }\end{array}$ \\
\hline
\end{tabular}

\section{DISCUSSION, CONCLUSIONS AND FUTURE WORK}

The research aimed to evaluate the effects of KiDS material among kindergarten pupils on their language learning and the significant difference on pretest and posttest of control and experimental group. The research was conducted in the Philippines among selected 27 pupils from kindergarten pupils for control and experimental group.

Moreover, to determine the effect of the KiDS material on the language listening comprehension of experimental and control group, the researcher employed t-Test for Independent group samples. The independent group t-test is a parametric statistical test that compares the means of two different samples of participants. It indicates whether the two samples perform so similarly that we could conclude they are likely from the same population, or whether they perform so differently that we conclude they represent two different populations [13].

Digital storytelling not only offers language teachers the opportunity of working with all four language skills from the very beginning, but also brings together the idea of combining the art of telling stories with a variety of digital multimedia such as images, recorded audio narration, video and music [18]. There are many ways to facilitate self-access language learning using technology [4].In particular, having easy access to recording tools can support the unlimited communicative practice that assists language learners in building knowledge for communicative competence. These tools are also able to support an alternative assessment method so as to provide an autonomous learning environment in which learners can practice speaking and check performance data to monitor their learning progress. Such concept is the same with [19], [25], [10], [18], [2] and [15].

In particular, having easy access to recording tools can support the unlimited communicative practice that assists language learners in building knowledge for communicative competence. These tools are also able to support an alternative assessment method so as to provide an autonomous learning environment in which learners can practice speaking and check performance data to monitor their learning progress. Accordingly, teachers are willing to use digital storytelling to provide more effective instruction [21]. [24] Studied digital storytelling with eight year old children in an integrative science classroom handsome environment and suggested that using digital storytelling affects the self-reflection and the construction of science knowledge in primary school children.

In this study, children in the experimental group enjoyed listening the storytelling while watching, which is a manifestation that they are all motivated. As a result, they are able and very eager to answer the question and showed active participation during the discussion. Likewise, 
The International Journal of Multimedia \& Its Applications (IJMA) Vol.10, No.6, December 2018

pupils in the experimental group developed higher language listening comprehension skills as shown in the result of the formative test and post test where they got high scores than the pupils in the control group. This finding is justified by the different researchers and studies wherein learners develop language skills that make them interactive and active learners. Hence, [5] mentioned that the development of students' listening skills could be enriched easily by watching digital stories. Consequently, as listening activities accompanied by watching could be more influential, listening texts in language arts course books could be supported by multimedia. Teachers could use and/or produce digital stories instead of using traditional CDs, which do not include any visuals, or instead of reading the listening texts aloud.

The result revealed that digital storytelling is an effective way of proving instruction especially in giving storytelling. It flourishes learning than use the traditional way of storytelling. Traditional storytelling shows no development on language learning compare when use digitalized storytelling among kindergarten pupils. Lastly, it can be conclude that the Kindergarten pupils who undergone through the use of digitalized storytelling shows development on language learning through listening comprehension. Language can be developed through the use of digital storytelling. Hence, listening is one way to enhance the capacity in learning the language.

In light with the conclusions the following recommendations were given. For the effectiveness of storytelling teachers should use creative way to attract the pupils, which considers the good design of digital storytelling. Thus, the administration should recommend the use of digital storytelling and take advancement in providing instruction for the learners. They should also provide teacher's technical assistance/training on how they will chose digital storytelling. Likewise, teachers should always apply technology advancement in facilitating the teaching and learning process in language for it will arouse student's interest. Hence, they could use localized digital storytelling materials that will make their instruction more effective. Moreover, teachers are recommended to focus on language learning through listening comprehension in teaching kindergarten pupils since it is big factor for the young learners to enhance their language listening skills.

\section{ACKNOWLEDGMENTS}

We are very grateful to the administration of Philippine Normal University and University of Pendidikan Sultan Idris for the support and assistance to materialize this project.

\section{REFERENCES}

[1] 1987 Philippine constitution article XIV, section 12. Accessed on June 16, 2016 from http://www.gov.ph/constitutions/the 1987-constitution-of -the-republic- of- the-philippines/

[2] Atta-Alla, M. N. (2012). Integrating language skills through storytelling. English Language Teaching, $5(12), 1-2$

[3] Brett, P. (1995). Multimedia for listening comprehension: The design of a multimedia-based resource for developing listening skills. System,23(1), 77-85.

[4] Castellano, J., Mynard, J \&Rubesch, T. (2011). Student technolgy use in a self-access center. Language learning and technology, 15(3), 12-27 Retrieved December 9, 2017 from https://www.learntechlib.org/p/52233

[5] Cigerci, F. M., \& Gultekin, M. (2017). Use of digital stories to develop listening comprehension skills. Issues in Educational Research, 27(2), 252-268. 
The International Journal of Multimedia \& Its Applications (IJMA) Vol.10, No.6, December 2018

[6] Creswell, J. W. (2012). Research design: Qualitative, quantitative, and mixed methods approaches. New York, NY: Sage

[7] Guidelines on the implementation of the Deped Computerization Program (DCP). (June 10, 2010). Retrieved July 6, 2017, from http://www.deped.gov.ph/orders/do-78-s-2010

[8] Explorable. (2009). Non-probability sampling. In Explorable: Think Outside the Box. Accessed on May 15, 2017 from https://explorable.com/non-probability-sampling.

[9] Fidelman, C. G. (1997). Extending the language curriculum with enabling technologies: Nonverbal communication and interactive video. NEXUS:The convergence of language teaching and research using technology, 28-41.

[10] Gassin, J. (1992). Interkenesics and interprosodics in second language acquisition. Australian Review of Applied Linguistics, 15(1), 95-106.

[11] Gregori-Signes, C. (2008). Integrating the old and the new: Digital storytelling in the EFL language classroom. A Journal for Teachers of English, 16(1), 43.

[12] Haddad, W.D. \&Jurich, S. (2002). ICT for education: Potential and potency. Technologies for education: Potential, parameters and prospects. UNESCO and Academy for Educational Development, 28-40.

[13] Hartley, J. \&McWilliam, K. (2009). Story circle: digital storytelling around the world. Chichester: Wiley-Blackwell.

[14] Jackson, S. (2016). Research Methods and Statistics: A critical thinking approach. United Kingdom: Thompson Wadsworth.

[15] Kim, M. (2010). The effects of storytelling on adult English language learners. Linguistic Research,27(3), 447-473.

[16] Lyudumila, A. J. (2013). The effectiveness of digital stories on listening comprehension ( University of Technology Malaysia), (Master's thesis). Retrieved from http://eprints.utm.my/id/eprint/42254/

[17] Oduolowu, E \&Akintemi, E. O. (2014). Effects of storytelling on listening skills of primary one pupil in Ibadan local government area of Oyo State Nigeria. International journal of humanities and social sciences, 4(9), 100-107.

[18] Ramirez-Verdugo, D., \& Belmonte, I. A. (2007). Using digital stories to improve listening comprehension with Spanish young learners of English. Language Learning \& Technology, 11(1), 87- 101.

[19] Robin, B. R. (2006). The educational uses of digital storytelling. In C. Crawford (Ed.), Proceedings of Society for Information Technology \& Teacher Education International Conference2006, 709716. doi: http://digitalstorytelling.coe.uh.edu/articles/Educ-Uses-DS.pdf

[20] Robin, B.R., \& McNeil, S.G. (2012). What educators should know about teaching digital storytelling? Digital Education Review, 22, 37-51

[21] Ross K. N. (2005). Sample design for educational survey research. In K.N. Ross (Ed). Quantitative research methods in educational planning. Paris France: United Nations Educational, Scientific and Cultural Organization (UNESCO)- International Institute for Educational Planning (IIEP) pp 1-83

[22] Sadik, A. (2008). Digital storytelling: a meaningful technology-integrated approach for engaged student learning. Educational Technology Research and Development, 56(4), 487-50. 
The International Journal of Multimedia \& Its Applications (IJMA) Vol.10, No.6, December 2018

[23] Sarrab, M. Elagamel, L. \&Aldaabbas, H. (2012). Mobile learning (m-learning) and educational environments. International Journal Distributed and Parallel Systems, 3(4), 31-38.

[24] Valkanova, Y. \& Watts, M. (2008). Digital storytelling in a science classroom: reflective self-learning (RSL) in action. Metacognitive Approaches to Promoting Oracy-Developing Speaking and listening with young children, Evans, R..\& Jones, D. (Eds.), New York: Routle, pp 225-241. ISBN 0415447666

[25] Van Scoter, J., Ellis, D., \&Railsback, J. (2001). Technology in early childhood education: Finding the balance. Portland, OR: Northwest Educational Technology Consortium.

[26] Wang, S. (2010). Enhancing teaching and learning with digital storytelling. International Journal of Information and Communication Technology Education (IJICTE), 6(2), 76-87.

[27] Woottipong, K. (2014). Effect of using video materials in the teaching of listening skills for university students. International Journal of Linguistics, 6(4), 200-212.

\section{AUTHORS}

Prof. Amor F. Loniza is an Assistant Professor II at Philippine Normal University South Luzon Campus Lopez, Quezon Philippines. She is currently completing her Ph.D in Early Childhood Education at University of Pendidikan Sultan Idris Malaysia. She earned her Internationa MA in child development in University of Haifa Israel in 2016 and Master of Arts in Education major in administration and supervision at University of Northeastern Philippines in 2007. She has been teaching in the Department of Education Lopez West Distirct from 1998 to 2005 and at Philippine Normal University from 2005 to date, handling Professional education subjects such as Child Psychology, Children's Literature, Special Education, Developmental Reading, Practice Teaching and Physical Education.

Prof. Madya Dr. AslinaSaadis an Associate Professor in Computiing Department, Faculty of Art, Computing Department and Creative Industry UPSI. She obtained her PhD in Computer Science from University of Loughborugh, England in 2011. She is a graduate in Master of Science in Information Technolgy, UTM and Bachelor of Information Technology (Science and System Management), UKM. Her research interests are on Computer Education, Information System, Artificial Intelligence and Software Engineering. She has been teaching since 2002 in various courses susch as Database System, ICT principles, System Analysis and Design, Software Design, Software Project, Software Process, Information System Development and Object Oriented Analysis and Design.

Dr. Mazlinabinti Mustafa is a senior lecturer DS52 in Faculty of Human Development at University of Pendidikan Sultan Idris, Malaysia. She earned her Doctor of Philosophy in Education at Canterburry University New Zealand in 2015, IjazahSarjana in Early Childhood Education in MacquairieUnversity, Sydney Australia in 2004 and IjazahSarjana Muda (TESL) at Heriot Watt University, Edinburgh, UK in 1998. Her reaerch interest are on Teaching English to Preschool Children, Socio Econmic Competency of young children and Early Childhood Policy and Services.
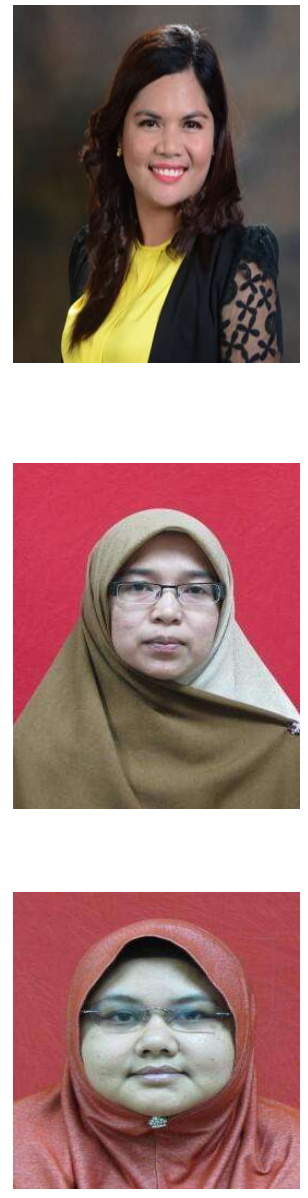